\title{
Using evidence on violence and injury prevention for policy development and decision making in Ciudad Juarez, Mexico
}

\author{
Luis Alberto Gutiérrez, ${ }^{1}$ Sergio Pacheco, ${ }^{2}$ Alethia Yurithzi Juárez, ${ }^{2}$ \\ Luis Alexandro Palacios, ${ }^{3}$ and Maria Teresa Cerqueira ${ }^{1}$
}

Suggested citation Gutiérrez LA, Pacheco S, Juárez AY, Palacios LA, Cerqueira MT. Using evidence on violence and injury prevention for policy development and decision making in Ciudad Juarez, Mexico. Rev Panam Salud Publica. 2012;31(5):365-72.

\begin{abstract}
This report describes the implementation process and functional structure of the Observatory of Security and Citizen Conviviality of the Juarez Municipality (Observatorio de Seguridad y Convivencia Ciudadanas del Municipio de Juárez) in Chihuahua, Mexico, and discusses the most relevant lessons learned and main challenges in the near future. The Observatory, created in 2008, is a joint effort of the Juarez Municipal Government, Autonomous University of Ciudad Juarez (Universidad Autónoma de Ciudad Juárez), and the Pan American Health Organization. The Observatory's main objective is to propose strategies and public policy recommendations to prevent and control violence and injuries in the Juarez Municipality. Most key federal, state, and local agencies have joined this independent autonomous citizen-based initiative, feed the databases, and benefit from the information produced by a multisectoral, multidisciplinary approach. The Observatory contributes far more than the technical data provided and its facilitating functions. The clear results obtained in such a short time-as seen in the preliminary results of the case study on road injuries from January 2009 to July 2011demonstrate the appropriateness of this course of action and should stimulate the creation of new observatories whenever and wherever needed. Lessons learned, as discussed here, can open the way to new endeavors, and current challenges show how much work remains to be done.
\end{abstract}

Key words Epidemiologic surveillance; violence; accidents, traffic; geographic information systems; border health; Mexico; United States.

Ciudad Juarez, at the United StatesMexico border, the most populated of all municipalities in Chihuahua State, is 1 of the 10 largest cities in Mexico, with 1332131 inhabitants (1). Violence in the area increased significantly from

\footnotetext{
United States-Mexico Border Office, Pan American Health Organization, El Paso, Texas, United States of America.

2 Observatorio de Seguridad y Convivencia Ciudadanas, Universidad Autónoma de Ciudad Juárez, Ciudad Juárez, Chihuahua, Mexico. Send correspondence to: Sergio Pacheco, sergio.pacheco@uacj.mx

3 Instituto Municipal de Investigación y Planeación, Ciudad Juárez, Chihuahua, México.
}

2007 to 2010 (2). During that period, the homicide rate increased from 23 to 224 per 100000 inhabitants, and in 2011 there were still a very large number of deaths due to external causes [data from the Observatory of Security and Citizen Conviviality of the Juarez Municipality (Observatorio de Seguridad y Convivencia Ciudadanas del Municipio de Juárez) in Chihuahua, Mexico]. This situation triggered the concerns and actions of local, state, and national authorities as well as involvement of civil society.
In spite of reports on homicides, violence, death, and injury due to external causes, scattered and faulty information made it impossible to fully understand the magnitude and characteristics of the different types of violence, its roots, and the mortality burden. Furthermore, critical data on violence from different sources were not shared and information was missing, thus hindering a comprehensive analysis of violence and injuries. These factors limited the timely compilation of evidence for policy and 
decision makers to implement appropriate programs. The lack of multisector, comprehensive, and timely information made it practically impossible to improve conditions in the community and for the city to prevent events leading to acts of violence such as partner violence, violence against women, gang violence, child sexual abuse, and road injuries.

A historic meeting of civil society organizations with the public and private sectors was convened in $2008^{4}$ by the Autonomous University of Ciudad Juarez (Universidad Autónoma de Ciudad Juárez, UACJ), the municipal government, and the Pan American Health Organization (PAHO) to identify key issues to be addressed in public policies. Approximately 200 representatives of community organizations as well as public and private institutions and experts from $\mathrm{PAHO}$, the National Center for Accident Prevention (Consejo Nacional para la Prevención de Accidentes, CENAPRA), and the Colombian Institute for Research and Development in Violence Prevention and Promotion of Social Conviviality (Instituto de Investigación y Desarrollo en Prevención de Violencia y Promoción de la Convivencia Social, CISALVA) convened to review the available information and propose immediate actions. Injuries from external causes were confirmed as the main problem of this prosperous municipality. It was clear that solving such a complex problem required combined multisector efforts and a credible source of validated and wellelaborated information.

This community consultation resulted in several lines of action, one of which was the creation of an observatory to monitor violence, designed under the recommended guidelines of $\mathrm{PAHO}$ and CISALVA $(3,4)$. Another recommendation was to implement evidence-based programs and policies to prevent violence and injuries in key settings. Several types of violence were identified: domestic violence (in homes and families), bullying (in schools), occupational injuries (in the workplace), and delinquency and other types of violence (in the community).

The known observatory methodologies enable a more interdisciplin-

\footnotetext{
4 Organización Panamericana de la Salud. Implementación y experiencia del Observatorio de Seguridad y Convivencia Ciudadanas del Municipio de Juárez, Chihuahua, México. Manuscript in preparation.
}

ary analysis of problems by involving multiple sectors, including health, justice, police, traffic, education, development, housing, parks and recreation, and community leaders and representatives (4).

In this framework, the Observatory of Security and Citizen Conviviality of the Juarez Municipality was created in November 2008 through the joint efforts of the Juarez Municipal Government, the UACJ, and PAHO through its United States-Mexico Border Office. Most key agencies of Juarez Municipality joined this independent autonomous citizenbased initiative.

The setting for the Observatory involved a core investment so that many agencies could work together to improve social conditions in Ciudad Juarez and create effectively proven synergies. The Observatory uses a comprehensive multidisciplinary approach that views violence and injuries as preventable public health problems (5).

The overall goals of the Observatory are to propose strategies to prevent and control violence and injuries and to design public policy recommendations to enhance citizen safety and conviviality in the Juarez Municipality.

These goals are reached through the evidence generated by the Observatory. Therefore, the Observatory had to establish a reliable, flexible, timely, and sustainable information system with the support of authorities from participating institutions and civil groups. For a secure citizenry and a peaceful community, the Observatory should identify trends, provide validated analyses of models and violence typologies, and produce sound indicators of the current situation.

The information and analytical tools produced by this coordinated effort give a clear and comprehensive picture of deaths due to external causes and a detailed map of the hotspots of violence in the municipality. This information system also keeps track of appropriate indicators and monitors the effect of public policies and interventions on the improvement in the health and safety of the entire population.

This report describes the implementation process and functional structure of the Observatory and discusses the most relevant lessons learned and main challenges in the near future.

\section{THE OBSERVATORY: A MULTISECTORAL, MULTIDISCIPLINARY PROJECT}

Bringing together many institutions to focus on one rather complex objective (Figure 1) was a challenging task because of the difficulty of building enough trust among the many stakeholders to share data for the Observatory. UACJ is a highly recognized, credible, and respected institution in Ciudad Juarez and the fact that many leaders and authorities were trained there facilitated the decision to place the Observatory on its premises. Support from PAHO and the municipal government was also a critical factor in successfully setting up the Observatory. Other critical elements were the leadership and resources provided by UACJ, PAHO, and Juarez Municipality.

The greatest barriers arose from the specific interests of each participating institution; this problem was settled by reaching a consensus on which information was to be most readily available and which posed the fewest conflicts, which led to considering road injuries as the starting point.

\section{Organization structure and input information}

The structure and components of the Observatory are presented in Figure 2. The Steering Committee oversees the strategies and progress of the Observatory, works with the Technical Secretariat to coordinate and ensure implementation of Observatory activities, and monitors execution of the strategic plan (5). The Steering Committee defined the fields of action to cover all cases of violence (particularly those against women, girls, boys, and adolescents), homicides, occupational and road injuries, crimes, and public perception of insecurity in the Juarez Municipality.

The general idea of the Observatory encompasses building a sustainable data input network, with participation of agencies at all government levels (federal, state, and local) in charge of monitoring deaths and injuries due to external causes, both intentional and accidental. Nongovernmental organizations and institutions may also provide information.

The number of variables and records varies in the different Observatory data- 
FIGURE 1. Institutions participating in the Observatory of Security and Citizen Conviviality of the Juarez Municipality, Ciudad Juarez, Chihuahua, Mexico, 2008

\begin{tabular}{|c|c|}
\hline $\begin{array}{l}\quad \text { Juarez Municipal Government } \\
\text { - Coordination of General Administrations } \\
\text { - General Municipal Traffic Division } \\
\text { - General Public Construction Works Administration } \\
\text { - General Public Services Administration } \\
\text { - Institute for Integral Family Development } \\
\text { - Municipal Public Security Secretariat } \\
\text { - Social Communication Secretariat } \\
\text { - Informatics Administration } \\
\text { - Municipal Institute for Research and Planning } \\
\text { - General Ecology and Civil Protection } \\
\text { Admininistration }\end{array}$ & $\begin{array}{l}\quad \text { State Government of Chihuahua } \\
\text { - Chihuahua State Secretariat of Health } \\
\text { - Forensic Medicine Service } \\
\text { - Northern Zone Deputy Attorney's Office } \\
\text { - State Secretariat of Education and Culture } \\
\text { - Coordination of Safe Schools } \\
\text { - State Office of Civil Pensions } \\
\text { - State Center Against Addictions } \\
\text { - Chihuahua Institute of Health } \\
\text { - Women's Hospital } \\
\text { - State Network of Organizations for the } \\
\text { Prevention of Violence }\end{array}$ \\
\hline & \multirow[b]{2}{*}{$\begin{array}{l}\text { Nongovernmental Institutions } \\
\text { - Ciudad Juarez Autonomous University } \\
\text { - Pan American Health Organization } \\
\text { - Institute for Research and Development in } \\
\text { Violence Prevention and Promotion of } \\
\text { Social Conviviality, Colombia } \\
\text { - Center for the Prevention and Care of Women } \\
\text { in Violent Situations } \\
\text { - Colegio de la Frontera Norte } \\
\text { - Medical Association } \\
\text { - Colegio de Chihuahua } \\
\text { - Red Cross } \\
\text { - Centers for Youth Integration }\end{array}$} \\
\hline $\begin{array}{l}\text { Federal Government } \\
\text { - Federal Secretariat of Health } \\
\text { - National Center for the Prevention of } \\
\text { Traffic Accidents } \\
\text { - Ciudad Juarez Local Health Department, } \\
\text { Jurisdiction II } \\
\text { - Citizen's Participation Council of the } \\
\text { Attorney General's Office } \\
\text { - Secretariat of Public Education } \\
\text { - Mexican Institute of Social Security } \\
\text { - National Attorney General's Office } \\
\text { - Federal Labor and Welfare Secretariat }\end{array}$ & \\
\hline
\end{tabular}

FIGURE 2. Structure of the Observatory of Security and Citizen Conviviality of the Juarez Municipality, Ciudad Juarez, Chihuahua, Mexico, 2008

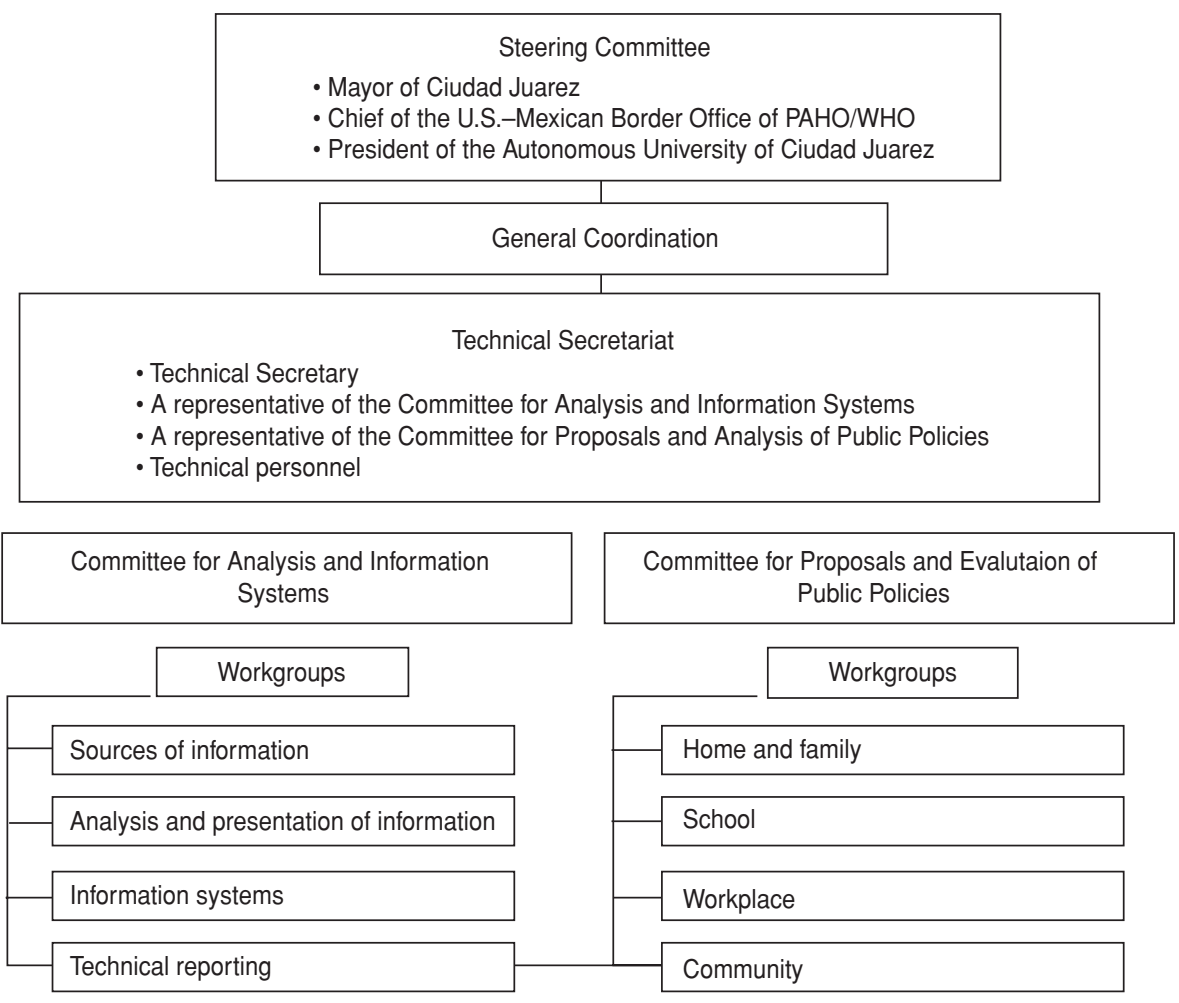

Note: PAHO/WHO: Pan American Health Organization/World Health Organization. bases, from 125 variables and some 20000 records from death certificates issued since 2008 to more than 11 variables and 1200000 traffic violations that have been recorded since 2009 .

\section{Basic elements}

Data collection and validation are the start of an extensive and complex process of information management involving the Observatory's comprehensive information system, made up of five elements constituting a shared technological infrastructure.

The Automated Indicator System (Sistema Automatizado de Indicadores) makes information exchange between participating agencies swift and easy in a controlled, secure environment. It offers predefined reports intended for public viewing (http://datos.observatoriode Juarez.org:8080/sistemasai / DGTM / reportes.aspx) and dynamic reports for authorized persons to obtain different perspectives of a problem (http://datos.ob servatoriodeJuarez.org:8080/sistemasai/).

The geographic information system provides charts and maps with georeferenced events to allow municipal agencies to carry out timely actions. For road injuries, for example, the Observatory released public dynamic maps showing the wide range of incidences in 2010 (http:/ / mapas.observatoriodeJuarez. org/transito2010/).

The three remaining basic elements are the website (http://observatoriode Juarez.org), newsletters (http://obser vatoriodeJuarez.org/dnn/Boletines. aspx), and a technical information repository (http:/ / www.infofrontera.org).

\section{CASE STUDY: ROAD INJURIES IN CIUDAD JUAREZ}

Road injuries, car crashes, and pedestrian injuries are the most frequent and preventable injuries due to external causes in the world (6). In Mexico, road injuries are in first place, causing more than $50 \%$ of reported injuries in many urban areas $(7,8)$. Although violence has an important impact on all spheres of life at the U.S.-Mexico border, more rapid and effective results can be achieved by preventing road injuries. The World Report on Road Traffic Injuries (9) states that road injuries are not randomly distributed along roads; instead, they occur 
at specific locations and intersections depending on road conditions and conditions of drivers and passengers.

Based on trends, geographic distribution of hotspots, and structural and human variables linked to reported road injuries, the Observatory provided a spatial diagnostic of road incidents for 2009 and 2010 in the Juarez municipal area.

Especially important for this taskalong with collecting, validating, and processing the input data from different sources-are the joint road audits, in which CENAPRA provides the methodology and certifies personnel as traffic auditors. CENAPRA, in collaboration with UACJ, also offers training courses on a wide range of traffic topics and, together with $\mathrm{PAHO}$, provides specialized equipment. Since the beginning of the collaboration between the Juarez General Municipal Traffic Division and CENAPRA in 2009, these activities have increased considerably and road safety has been technically strengthened. To-

TABLE 1. Indicators created by the Observatory of Security and Citizen Conviviality of the Juarez Municipality, Ciudad Juarez, Chihuahua, Mexico, 2008

\section{Indicator}

Road safety

Evolution of road incidents

Rate of road incidents per 100000 inhabitants

Rate of responsibility in road incidents per 1000 motor vehicles, according to type of vehicle

Population density $\left(\mathrm{km}^{2}\right)$

Total road density

Car ownership rate (motor vehicles per 100000 inhabitants)

Rate of road incidents per 100000 inhabitants

Rate of road incidents per 100000 private motor vehicles

Rate of persons involved in road incidents per 100000 private motor vehicles

Rate of persons involved in road incidents per 100000 inhabitants

Rate of road incidents per 100000 registered drivers

Death rate per 100 incidents

Death rate per 100000 inhabitants

Rate of injured persons per 100 incidents

Rate of injured persons per 100000 inhabitants

Domestic violence

Rate of child abuse per 1000 persons under 18 years of age

Rate of domestic violence per 100000 inhabitants

Rate of sexual violence per 100000 inhabitants

Homicide

Rate of homicides per 100000 inhabitants

Rate of femicides per 100000 inhabitants

Death rate due to firearms per 100000 inhabitants

Maps created for each of the eight sectors of the city

General statistics of traffic incidents

Frequency of traffic incidents due to crashes

Intersections with car-pedestrian crashes and rollover accidents

Intersections according to type of involvement in road incidents: responsible and affected

Intersections according to condition of victims of road incidents: injured and dead

Statistics of intersections

Areas and intersections with a high frequency of road incidents

Statistics of main thoroughfares

Main thoroughfares with incidents in 2010

gether with the Observatory and the Juarez General Municipal Traffic Division, many other local authorities participate in the audits to evaluate each from different viewpoints, inman and social causes as well traffic incidents from the security and ublic health perspectives.

A set of indicators was developed evaluate general road safety (Table . More than 50 variables were used data related to the incidents volved (category, make, model, regis ration, insurance, brake, and tire conditions), and persons involved (age, sex, se of safety devices, type of injury). ata have been compiled since January

The outputs provide crucial informaion to reduce road injuries and promote oad safety. This information is provided 
FIGURE 3. Map of reported road accidents in sector C of Ciudad Juarez, Chihuahua, Mexico, 2010; red zone shows intersections with the highest frequencies of road injuries

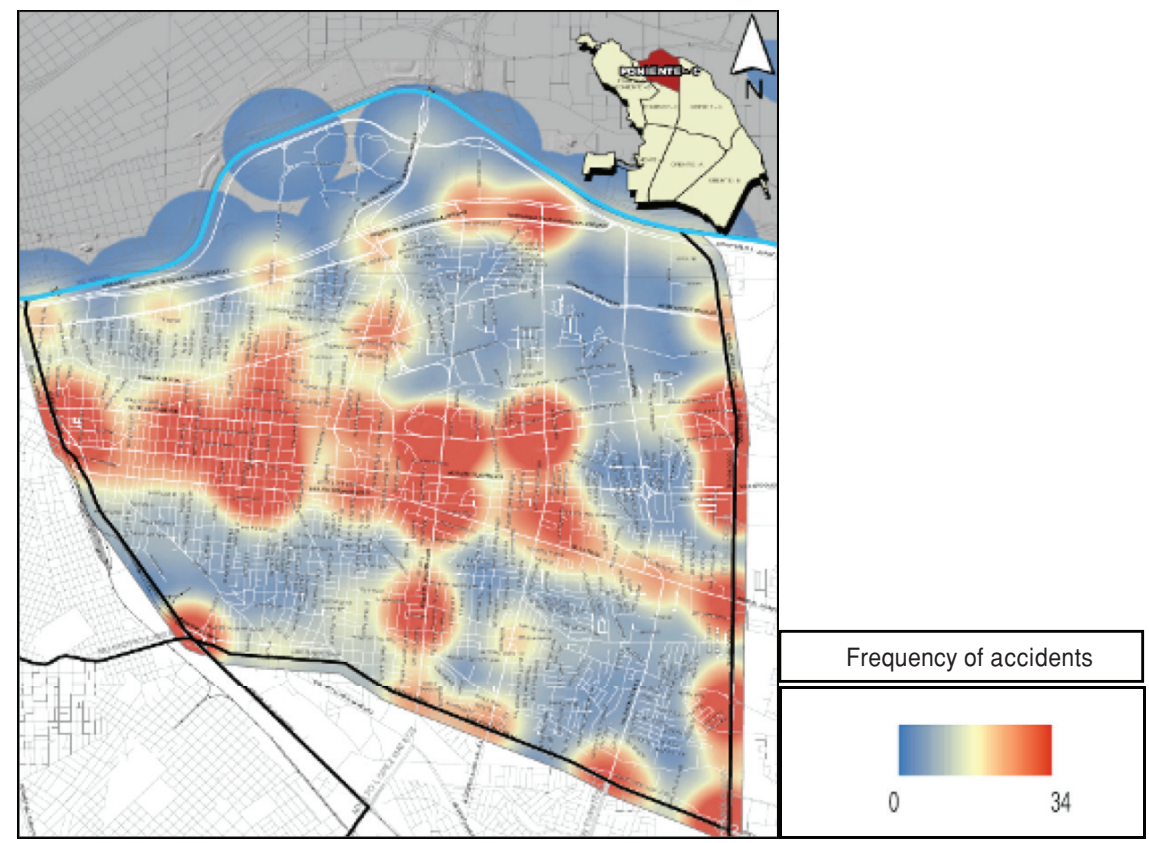

Source: Observatory of Security and Citizen Conviviality of the Juarez Municipality.

FIGURE 4. Dynamics of the frequency of traffic incidents by sector, Ciudad Juarez, Chihuahua, Mexico, 2007-2010

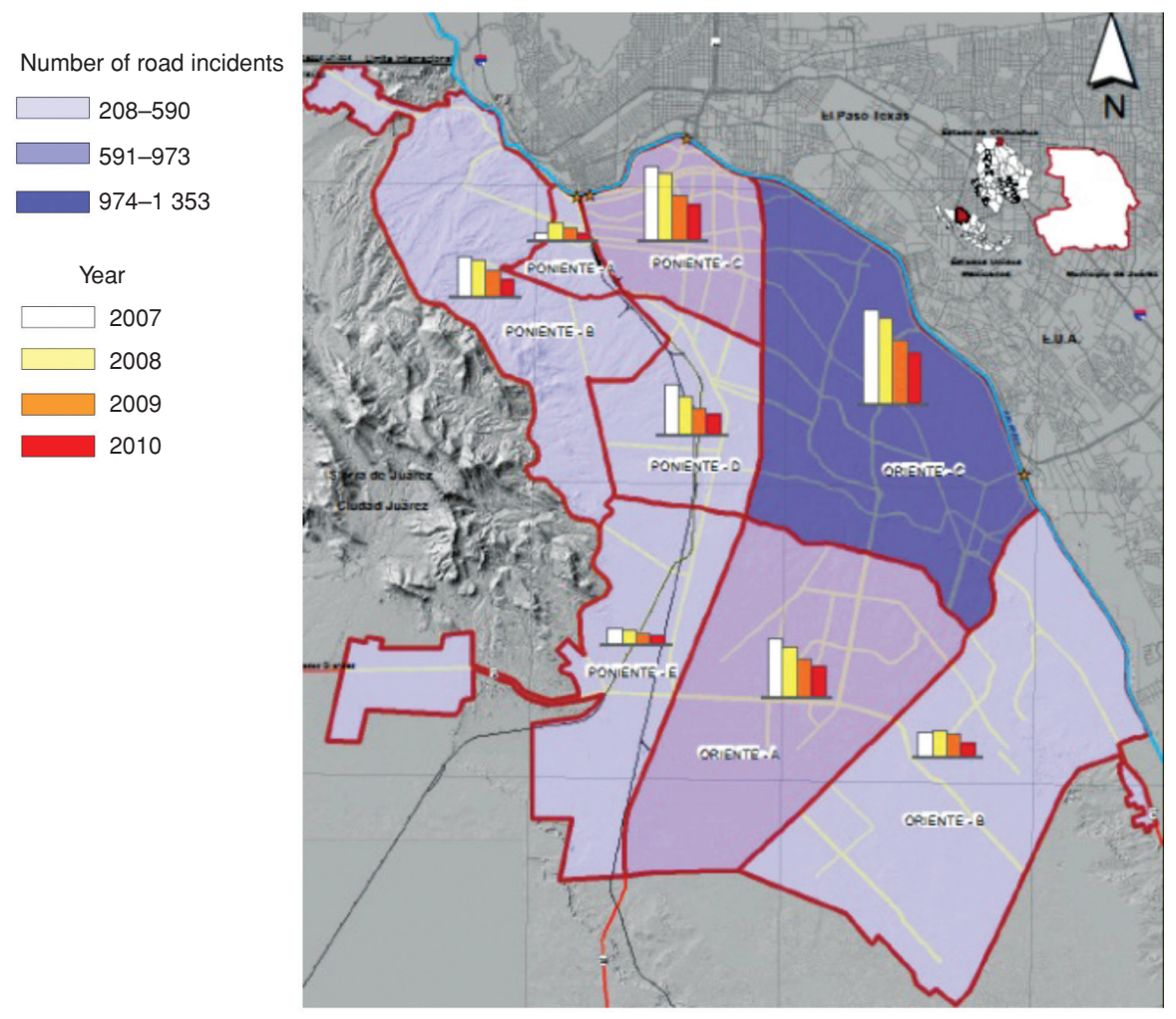

Source: Observatory of Security and Citizen Conviviality of the Juarez Municipality.

\section{LESSONS LEARNED AND CHALLENGES}

The use of observatories in collecting and analyzing information on relevant epidemiologic issues as well as proposing and monitoring measures to improve population health and safety is well established $(4,5,10,11)$. Violence is a major cause of high morbidity and mortality in many countries, thereby becoming the target of observatories that focus on domestic and gender violence (12-15), armed social violence $(10,16)$, juvenile violence (17), and crime (18). Regardless of the type and scope of observatories, procedures are similar in that they collect information, validate and analyze data, write reports, and disseminate results. The Observatory follows that procedure.

The number and type of indicators vary among observatories, depending on their scope and the area covered. In any case, every observatory must continuously analyze information and include new indicators when advisable, depending on the situation and context. One of the most complete sets of indicators in our region is that of the Hemispheric Observatory on Citizen Security (19).

The experience of the Juarez Observatory has shown that even in complex situations, academic institutions, international organizations, and diverse governmental and nongovernmental institutions and organizations can combine efforts and collaborate.

Factors contributing to the Observatory's success can be summarized as follows:

- Combination of the political will of the municipal government and UACJ, the convening power of PAHO's technical cooperation, and the technical expertise of CISALVA;

- Permanent commitment of the members of the Steering Committee and Technical Secretariat, with joint participation of staff from the PAHO U.S.Mexico Border Office, UACJ, and the Juarez Municipality and support from other institutions and stakeholders;

- Resources contributed by UACJ, PAHO, and the Juarez Municipality during the implementation phase;

- Acknowledgment of the important contributions of the Observatory and its local, statewide, national, and international benefits; 
FIGURE 5. Frequency of road incidents with participation of drunk drivers, ${ }^{\text {a Ciudad Juarez, Chihuahua, Mexico, January } 2009-J u l y ~ 2011}$

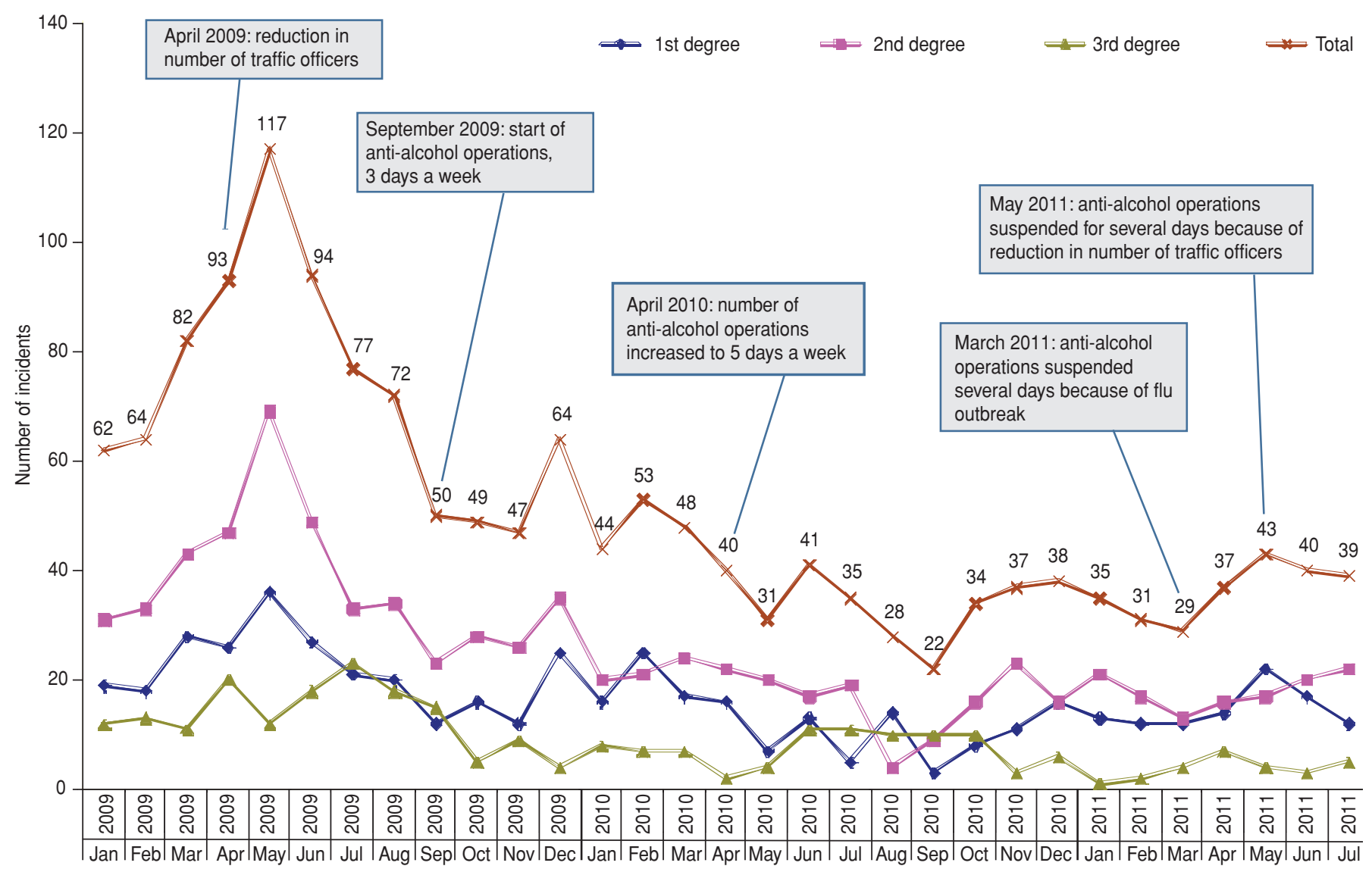

Year, month

Source: Observatory of Security and Citizen Conviviality of the Juarez Municipality, Automated Indicator System with data provided by General Municipal Traffic Division.

a Alcohol intoxication degree, measured in percentage of milligrams of alcohol per liter of blood (blood alcohol concentration, BAC): 1 st degree, $0.090 \%$ to $0.139 \%$ BAC; 2 nd degree, $0.140 \%$ to $0.229 \%$ BAC; 3rd degree, $0.230 \%$ or higher BAC.

- Generation of relevant and critical information on the magnitude of the burden of violence and injuries, thereby creating visibility and awareness at many government levels and in many sectors;

- The high spirit of cooperation of all participating institutions, considering that the Observatory is a common asset; and

- Significant community participation.

To enhance the impact of the Observatory, many challenges remain:

- Continuing technological improvement (software and hardware) in all institutions and increasing technical know-how of staff;
- Including information from new sources to provide a more comprehensive analytical view and increase the scope of the measured events;

- Formulating improved action plans that respond to the needs and requirements of the institutions and community, ensuring the use of the information produced;

- Ensuring the availability of resources to strengthen and guarantee the well functioning of participating institutions and the Observatory;

- Strengthening the infrastructure of all participating institutions, which are the backbone of the Observatory;

- Improving the conceptual framework and operational definitions for better data quality and analyses;
- Expanding and standardizing the set of indicators and working variables;

- Ensuring the participation of all institutions in the analysis and use of information and not only in providing data; and

- Reducing underreported events not conveyed to the authorities.

\section{CONCLUSIONS AND RECOMMENDATIONS}

The Observatory of Security and Citizen Conviviality of the Juarez Municipality provides evidence on different types of violence and injuries that affect the population and reveals risk factors and main causes. Its sustained convening power and validated outputs have 
shown that it is a proven and qualified voice advocating for the implementation of policies and programs to strengthen conviviality and reduce insecurity in Juarez Municipality.

The Observatory contributes far more than technical data and its facilitating functions. Lessons learned will open the way to new endeavors and current challenges show how much work is still needed. But the clear results obtained in such a short time demonstrate the appropriateness of this course of action and should stimulate the creation of new observatories whenever and wherever needed.

A crucial condition for the Observatory is the sense of ownership of all participating institutions; although UACJ provided the building block for future sustainability, these institutions must be motivated through ownership and participate fully.

Resources are essential for sustainability, as the Municipal Institute for Research and Planning is strongly dependent on municipal budgets and all participating institutions are affected by economic restrictions. By strengthening the analytical capacity of the Observatory and enhancing the reach of information to a wider audience, it may gain the needed sustainability.

Although the support and participation of the federal government is important, it should not become a barrier to local capacity building and decision making. Federal government bodies normally want to have the leading voice; a critical lesson in this case was to ensure that lo- cal institutions are the driving force at all times. In fact, this may be the strongest recommendation for similar projects.

Acknowledgments. The authors thank all governmental and nongovernmental institutions and organizations participating in this project. Special thanks go to the authorities of the Juarez Municipal Government and its local branches, UACJ, and PAHO for their fundamental work and involvement. We thank Alicia Rodríguez for her assistance in writing this article.

Conflict of interest. Authors LAG, SP, AYJ, and MTC were professionally involved in setting up or working at the Observatory of Security and Citizen Conviviality of the Juarez Municipality.

\section{REFERENCES}

1. Instituto Nacional de Estadísticas, Geografía e Informática. Censo de población y vivienda 2010. México, D.F.: 2011. Available from: http://www.inegi.org.mx/sis temas/olap/proyectos/bd/consulta.asp $? p=17118 \& c=27769 \& s=e s t \#$ Accessed 16 February 2012.

2. Costa G. La situación de la seguridad ciudadana en América Latina. Washington, D.C.: Diálogo Interamericano; 2012.

3. Organización Panamericana de la Salud. Sistematización de experiencias sobre sistemas de vigilancia, observatorios o sistemas de información de violencia en América Latina. Observatorios de violencia: mejores prácticas. Cali, Colombia: OPS, Inter-American Coalition for the Prevention of Violence, Banco Mundial, Instituto de Investigaciones y Desarrollo en Prevención de Violencia y Promoción de la Convivencia Social (CISALVA), Universidad del Valle; 2008.

4. Organización Panamericana de la Salud. Guía metodológica para la replicación de observatorios municipales de violencia. Cali, Colombia: OPS, Inter-American Coalition for the Prevention of Violence, Banco Mundial, Instituto de Investigaciones y Desarrollo en Prevención de Violencia y Promoción de la Convivencia Social (CISALVA), Universidad del Valle; 2008.

5. Observatorio de Seguridad y Convivencia de Juárez. Plan estratégico. Ciudad Juárez, México: Gobierno de Ciudad Juárez, Organización Panamericana de la Salud, Universidad Autónoma de Ciudad Juárez; 2010. Available from: http:/ /observatoriodeJuarez. org/dnn/Portals / 0/boletines/Plan_Estra tegico_del_Observatorio_de_Juarez.pdf Accessed 16 February 2012.

6. United Nations Road Safety Collaboration. Global plan for the Decade of Action for Road Safety 2011-2020. Geneva: WHO; 2011.
7. Consejo Nacional de Prevención de Accidentes. Perfil de accidentes de tránsitos en la República Mexicana. México, D.F.: CONAPRA; 2011. Available from: http://www.cenapra.salud. gob.mx/CENAPRA_2010/estadisticas/Perfil Nacional 2008.pdf Accessed 16 February 2012.

8. Instituto Nacional de Estadísticas, Geografía e Informática. Mortalidad por lesiones de causa externa y atropellamientos 1998-2007. México, D.F.: INEGI; 2008.

9. World Health Organization. World report on road traffic injury prevention. Geneva: WHO; 2007. Available from: http://www.who.int/ violence_injury_prevention/publications / road_traffic/world_report/en/ Accessed 16 February 2012

10. Gilgen E, Tracey L. Contributing evidence to programming: armed violence monitoring systems [working paper]. Geneva: UNDP; 2011. Available from: http://www.genevadeclaration.org/fileadmin/docs/general/ GD-WP-2011-Contributing-Evidence-to-Pro gramming.pdf Accessed 16 February 2012

11. Ramírez Arbeláez RD. Observatorio de violencia y seguridad ciudadana. Proyecto Agendas Locales para la Seguridad Ciudadana. Informe de evaluación externa. Santa Fe de Bogotá: Centro de Estudio y Análisis en Convivencia y Seguridad Ciudadana; 2009. Available from: http://idl-bnc.idrc.ca/dspace/bit stream/10625/46294/1/132781.pdf Accessed 16 February 2012

12. Cruz Moratones C. Perspectiva judicial de la violencia de pareja y doméstica en España. Rev Esp Med Legal. 2010;36(3):93-7.

13. Hernández Gutiérrez RI. Trata de personas y violencia de género en Tlaxcala. La experiencia del Observatorio de Tlaxcala. Segundo Congreso Latinoamericano sobre Trata y Tráfico de Personas: Migración, género y derechos humanos. Puebla, México; September 20-24, 2010. Available from: http://www.tratacon
greso2010.org/docs/Regina\%20Isabel\%20 Hern\%C3\%A1ndez\%20Guti\%C3\%A9rrez.pdf Accessed 16 February 2012.

14. Blotta MF, Fullone B, Fuentes A, Galizia B, Gancedo N. La violencia de género y el acceso a la justicia de las mujeres en la provincia de Santa Fe, Argentina. Rev Estud Jurídicos UNESP. 2011;15(22). Available from: http:/ / periodicos.franca.unesp.br/index.php/ estudosjuridicosunesp/article/view/472 Accessed 16 February 2012.

15. World Health Organization. Preventing intimate partner and sexual violence against women: taking action and generating evidence. Geneva: WHO; 2010.

16. Saldarriaga AFH, Salcedo M, Gutierrez Martinez MI. Violence observatory, strengths, weaknesses and results. Popayan an example of teamwork [abstract]. Inj Prev. 2010;16:A237. Available from: http://injuryprevention.bmj. com/content/16/Suppl_1/A237.2.abstract Accessed 16 February 2012.

17. International Juvenile Justice Observatory. Report of activities 2008-2010. Brussels: IJJO; 2011.

18. Wyvekens A. Evaluation of safety and crime prevention policies in France. A problematic activity. In: Robert P, ed. Evaluating safety and crime prevention policies in Europe. Brussels: VUBPRESS; 2009. Pp. 61-75.

19. Hemispheric Observatory on Citizen Security. Indicators. Washington, D.C.: Organization of American States; 2012. Available from: http://www.oas.org/dsp/observatorio/ database/indicators.aspx?lang=en Accessed 16 February 2012.

Manuscript received on 1 November 2011. Revised version accepted for publication on 30 April 2012. 
RESUMEN En este informe se describen el proceso de ejecución y la estructura funcional del Observatorio de Seguridad y Convivencia Ciudadanas del Municipio de Juárez, Chihuahua, México, y se presentan las enseñanzas extraídas más relevantes y los princi-

Uso de información sobre prevención de la violencia y las lesiones para la formulación de políticas y la toma de decisiones en Ciudad Juárez, México pales retos en un futuro próximo. El Observatorio, creado en el 2008, es un emprendimiento conjunto del gobierno del municipio de Juárez, la Universidad Autónoma de Ciudad Juárez y la Organización Panamericana de la Salud. El objetivo principal del Observatorio es proponer estrategias y recomendaciones de políticas públicas para prevenir y controlar la violencia y las lesiones en el municipio de Juárez. La mayoría de los organismos clave federales, estatales y locales se han sumado a esta iniciativa autónoma independiente de origen ciudadano, alimentan las bases de datos y se benefician de la información generada por el Observatorio mediante un enfoque multisectorial y multidisciplinario. El Observatorio aporta mucho más que datos técnicos y estrategias facilitadoras. Los claros resultados obtenidos en un tiempo muy breve - como los resultados preliminares del estudio de casos sobre lesiones en el tránsito llevado a cabo entre enero del 2009 y julio del 2011 - demuestran lo adecuado de este procedimiento y deben estimular la creación de nuevos observatorios dondequiera y cuandoquiera que se necesiten. Las enseñanzas extraídas analizadas en este informe allanan el camino hacia nuevos cometidos, y los retos actuales ponen de manifiesto que aún resta mucho trabajo por hacer.

Palabras clave Vigilancia epidemiológica; violencia; accidentes de tránsito; sistemas de información geográfica; salud fronteriza; México; Estados Unidos. 